\title{
Short communication: Responses to increasing amounts of free a-linolenic acid infused into the duodenum of lactating dairy cows
}

\author{
Khas-Erdene, ${ }^{*}$ J. Q. Wang, ${ }^{* 1}$ D. P. Bu, ${ }^{*}$ L. Wang, ${ }^{*}$ J. K. Drackley,† Q. S. Liu, ${ }^{*}$ G. Yang, ${ }^{*}$ H. Y. Wei, ${ }^{*}$ \\ and L. Y. Zhou* \\ *State Key Laboratory of Animal Nutrition, Institute of Animal Science, Chinese Academy of Agricultural Sciences, Beijing 100193, P. R. China \\ †Department of Animal Sciences, University of Illinois, Urbana-Champaign 61801
}

\begin{abstract}
Increasing the $\alpha$-linolenic acid (LNA; 18:3 cis-9, cis12, cis-15) content of milk fat might help promote consumers' health. The objective of this study was to determine the potential to alter the content of LNA in milk by duodenal infusion of a free fatty acid mixture rich in LNA. Four multiparous lactating Chinese Holstein cows fitted with duodenal cannulas were administered 2 treatments in a crossover design: an LNA-rich fatty acid infusion at varying concentrations $(0,40,80$, 120 , and $160 \mathrm{~g} / \mathrm{d}$ ) versus a basal infusate control. Dry matter intake was not affected by LNA infusions. Milk production tended to decrease and was quadratically affected as LNA infusion increased, but $4 \%$ fat-corrected milk yield was not changed. Milk fat content tended to increase linearly with LNA infusion. Milk protein content was not changed by LNA infusion, whereas milk lactose content and yield were decreased quadratically as LNA infusion increased. Increasing the amount of LNA infused into the duodenum linearly increased concentrations of $18: 3$ cis- 9 , cis-12,cis-15 (0.61 to 25.4 $\mathrm{g} / 100 \mathrm{~g}$ of total fatty acids) and 18:2 cis-9,cis-12 in milk fat. Increasing LNA decreased the percentages of 4:0, 14:0, and 16:0 fatty acids linearly. Increasing LNA also linearly decreased the percentages of $18: 1$ cis- 9 and 18:2 cis-9,trans-11 in milk fat. Milk fat content of $20: 5$ cis-5,cis-8,cis-11,cis-14,cis-17 was quadratically affected, whereas concentrations of 18:0, 18:1 trans-9, 18:1 trans-11, and 18:2 trans-10, cis-12 were not affected. Increasing the supply of $18: 3$ cis- 9 , cis- 12, cis- 15 to the small intestine linearly increased $18: 3$ cis- 9 , cis-12, cis- 15 in milk fat and markedly altered milk fat composition. Key words: lactating dairy cow, $\alpha$-linolenic acid, milk fatty acid, duodenal infusion
\end{abstract}

$\alpha$-Linolenic acid (LNA; 18:3 cis-9, cis-12, cis-15) is an n-3 long-chain fatty acid (LCFA) commonly

Received August 31, 2009

Accepted December 23, 2009.

${ }^{1}$ Corresponding author: jqwangcaas@gmail.com found in plants, but it is only found in small amounts in normal bovine milk fat ( $<1.0 \%$ by weight) because of ruminal biohydrogenation of dietary unsaturated fatty acids. As one of the major essential fatty acids, LNA can be converted into eicosapentaenoic acid and docosahexaenoic acid in the human body. $\alpha$-Linolenic acid has been shown to reduce inflammation and may help prevent chronic diseases such as heart disease and arthritis. It is highly concentrated in the brain, which may be particularly important for cognitive and behavioral health as well as normal growth and development (Connor, 1999). Thus, increasing the LNA content in milk fat might be beneficial to the health of consumers.

Milk fat content and composition can be affected by nutritional manipulation. Previous research has demonstrated that it is feasible to increase unsaturated LCFA in milk fat by infusing free LCFA into the abomasum (Litherland et al., 2005; Drackley et al., 2007), by infusing vegetable oils into the duodenum (Gagliostro and Chilliard, 1991), or by supplementing LCFA as calcium soaps or amides to increase the amount of unsaturated FA that escapes biohydrogenation in the rumen (Jenkins, 1998). However, the effects of an increased intestinal supply of LNA on milk fatty acids have not been well studied.

Dietary supplementation with LNA is a less feasible means to increase LNA in milk fat because of rumen biohydrogenation. To our knowledge, the greatest extent of enrichment of milk fat by dietary supplementation was achieved by supplementing linseed oil at $5 \%$ of dietary DM, which increased LNA to $2.46 \%$ of total milk fatty acid (Loor et al., 2005b). In other studies, milk LNA was slightly increased by supplementing LNA-rich oil (Loor et al., 2005a; Bu et al., 2007; Flowers et al., 2008), whole oilseeds (Petit et al., 2004, 2009), or rumen-protected fat (Petit, 2003). Another study showed that LNA was enriched to $15 \%$ of total milk fatty acid as the amount of linseed oil infused into the abomasum increased to $500 \mathrm{~g} / \mathrm{d}$ (Hagemeister et al., 1991). In that study, only 2 cows were studied and the LNA was infused as triacylglycerol (TG), which 
Table 1. Schematic of experimental design and treatments ${ }^{1}$

\begin{tabular}{|c|c|c|c|c|c|c|c|c|c|c|c|c|c|}
\hline Cow & $\frac{\text { Preliminary }}{\mathrm{Wk}-1}$ & \multicolumn{5}{|c|}{ Period 1} & \multicolumn{2}{|c|}{ Washout } & \multicolumn{5}{|c|}{ Period 2} \\
\hline 3860 & $\mathrm{~W}$ & 0 & 40 & 80 & 120 & 160 & W & $\mathrm{W}$ & 0 & 0 & 0 & 0 & 0 \\
\hline 2863 & W & 0 & 0 & 0 & 0 & 0 & W & W & 0 & 40 & 80 & 120 & 160 \\
\hline 746 & $\mathrm{~W}$ & 0 & 0 & 0 & 0 & 0 & W & W & 0 & 40 & 80 & 120 & 160 \\
\hline
\end{tabular}

${ }^{1} 0,40,80,120$, and $160=$ amount $(\mathrm{g} / \mathrm{d})$ of $\alpha$-linolenic acid-rich fatty acid infused (for $0 \mathrm{~g} / \mathrm{d}$ of $\alpha$-linolenic acid, cows received carrier in water); $\mathrm{W}=$ cows were infused with water only.

has been suggested to result in lower transfer rates than FFA (Litherland et al., 2005). However, the potential enrichment of LNA in milk fat via a greater postruminal free LNA supply remains to be determined. The objectives of this study were to evaluate the effects of duodenal infusion of increasing amounts of LNA on DMI, milk yield, and milk composition, and to determine the effects of postruminal LNA supply on FA composition of milk fat.

Four multiparous Chinese Holstein cows $(\mathrm{BW}=556$ $\pm 19 \mathrm{~kg}, \mathrm{DIM}=93 \pm 9 \mathrm{~d}$ ) that had been fitted previously with duodenal cannulas (2.5-cm inner diameter; Bar Diamond, Parma, ID) were used in a 2-treatment crossover design. Animals were handled and cared for following the guidelines approved by the Animal Care Advisory Committee of the Chinese Academy of Agricultural Sciences. The experimental design (Table 1) was essentially the same as that used previously (Drackley et al., 2007). Treatments consisted of infusion of basal infusate plus mixtures of FFA or the basal infusate only as the control. The basal infusate consisted of $15 \mathrm{~g} / \mathrm{d}$ of xanthan gum (Fufeng Fermentation Co. Ltd., Shandong, China), $5 \mathrm{~g} / \mathrm{d}$ of sodium alginate (Qingdao Bright Moon Seaweed Group Co., Qingdao, Shandong, China), and $25 \mathrm{~g} / \mathrm{d}$ of Tween 80 (Sigma Chemical Co., St. Louis, MO) in $10 \mathrm{~L}$ of pure drinking water. The LNA-rich FFA (Linuo Biochem Co. Ltd., Anyang, Henan, China) contained (weight basis) $82.4 \%$ 18:3 cis-9,cis-12,cis-15; $14.7 \% \quad 18: 2$ cis-9,cis- $12 ; 2.8 \%$ 18:1 cis-9; and $0.1 \%$ other fatty acids. The cows in both treatments were infused with the same volume of liquid during all experimental periods.

The experiment lasted for $13 \mathrm{wk}$, including a 1-wk preliminary period, two 5 -wk experimental periods, and a 2-wk washout period (Table 1). During each week of the 5-wk experimental periods, the 2 cows of the infusion group received $0,40,80,120$, and $160 \mathrm{~g} / \mathrm{d}$ LNA infusion sequentially, whereas the 2 control cows received only the basal infusate of the same volume for the entire $5 \mathrm{wk}$. Measurements were made during the last $3 \mathrm{~d}$ of each infusion week. At the end of first 5-wk experimental period, all cows were infused with water for a 2-wk washout period to eliminate carryover of the previous infusion before being switched to the other treatment for period 2 .

Infusates were prepared daily essentially as described by Drackley et al. (2007). The ingredients were mixed and heated to $72^{\circ} \mathrm{C}$ in steam-jacketed stainless steel vats and were then homogenized into stable emulsions with a homogenizer (model APV 1000, APV Manufacturing, Bydgoszcz, Poland) at 17.2 MPa during the first stage and 3.5 $\mathrm{MPa}$ during the second stage. Homogenized mixes were cooled and stored at $4^{\circ} \mathrm{C}$ until use. The control infusate and LNA infusate solutions were sampled each day and stored at $-20^{\circ} \mathrm{C}$ for fatty acid analysis to calculate the actual content of free LCFA. The predetermined volume of infusate for each cow was infused over 20 to $22 \mathrm{~h}$ daily. The infusates were pumped into the duodenum by using peristaltic pumps (model 205U Watson-Marlow Pumps, Falmouth, UK) via Norprene food tubing at 450 to $500 \mathrm{~g} / \mathrm{h}$ (Cole-Parmer Instrument Co., Vernon Hills, IL). The actual amounts of infused fat were recorded each day. The placement of the infusion line was checked each day before infusion to ensure that there was no leaking.

Cows were housed in individual tie stalls fitted with rubber mats and had continuous access to water from drinking cups. Cows were milked at 0700 and $1900 \mathrm{~h}$ and were allowed to exercise from 1700 to $1900 \mathrm{~h}$ daily. The lactation diet (Table 2) was fed as a TMR twice daily at the time of milking in amounts to ensure ad libitum intake. Amounts of feed offered and refused were recorded once daily. Samples for milk composition and fatty acid analysis were collected from the last $3 \mathrm{~d}$ of each infusion amount, including morning and evening milkings. One aliquot of each milk sample was stored with preservative (bronopol tablet; D\&F Control System Inc., Dublin, Canada) at $4^{\circ} \mathrm{C}$ until analyzed for milk fat, total protein, casein, lactose, and TS using infrared analysis (Foss MilkoScan, Foss Food Technology Corp., Eden Prairie, MN). The second aliquot was stored at $-20^{\circ} \mathrm{C}$ for analysis of fatty acid composition.

For milk fatty acid analysis, frozen milk samples from individual cows were thawed in a refrigerator at $4^{\circ} \mathrm{C}$ 
Table 2. Ingredient composition of diet fed to cows

\begin{tabular}{lc}
\hline Item & \% of DM \\
\hline Ingredient & \\
Alfalfa hay & 7.0 \\
Chinese wildrye & 22.0 \\
Corn silage & 21.0 \\
Corn & 23.0 \\
Wheat bran & 3.5 \\
Soybean meal & 10.5 \\
Cottonseed meal & 5.5 \\
Rapeseed meal & 4.0 \\
Calcium carbonate & 1.2 \\
Calcium phosphate, dibasic & 1.3 \\
Salt & 0.5 \\
Mineral-vitamin premix ${ }^{1}$ & 0.5 \\
Chemical composition & \\
NE ${ }^{2}$ Mcal/kg of DM & 1.55 \\
DM, \% & 51.9 \\
CP, \% of DM & 16.9 \\
NDF, \% of DM & 37.42 \\
ADF, \% of DM & 22.43 \\
Ether extract, \% of DM & 3.09 \\
Ca, \% of DM & 0.95 \\
P, \% of DM & 0.64 \\
\hline
\end{tabular}

${ }^{1}$ Contained (DM basis) Fe 5,500 mg/kg, Cu 4,080 mg/kg, Zn 17,500 $\mathrm{mg} / \mathrm{kg}$, Mn 4,980 mg/kg, Se $110 \mathrm{mg} / \mathrm{kg}$, I $180 \mathrm{mg} / \mathrm{kg}$, Co $88.5 \mathrm{mg} /$ $\mathrm{kg},>2,000 \mathrm{IU} / \mathrm{g}$ of vitamin $\mathrm{A}, 600 \mathrm{IU} / \mathrm{g}$ of vitamin $\mathrm{D}_{3}$, and $10.8 \mathrm{mg} / \mathrm{g}$ of vitamin $\mathrm{E}$

${ }^{2}$ The $\mathrm{NE}_{\mathrm{L}}$ values (Mcal/kg of $\mathrm{DM}$ ) used for alfalfa hay, Chinese wildrye, corn silage, corn, wheat bran, soybean meal, cottonseed meal, rapeseed meal were $1.19,1.12,1.45,1.91,1.61,2.38,1.71$, and 1.86, respectively (Chinese Feeding Standard, 2004).

and centrifuged at $17,800 \times g$ for $20 \mathrm{~min}$ at $8^{\circ} \mathrm{C}$ to separate fat. The fat cake $(1 \mathrm{~g})$ was transferred to a 5 -mL tube, and $20 \mathrm{mg}$ of the fat was esterified using the method described by Kramer et al. (1997). Separation of fatty acid was achieved by using an Agilent 6890 GC (Agilent Technologies, Hewlett Packard Co., Avondale, PA) fitted with a flame-ionization detector. Samples containing methyl esters in hexane $(1 \mu \mathrm{L})$ were injected through the split injection port (100:1) onto an SP-2560 fused silica $100 \mathrm{~m} \times 0.25 \mathrm{~mm}$ column with a 0.20- $\mu \mathrm{m}$ film (Supelco Inc., Bellefonte, PA). The oven temperature was initially $170^{\circ} \mathrm{C}$ for $30 \mathrm{~min}$, and was then increased to $200^{\circ} \mathrm{C}$ at $1.5^{\circ} \mathrm{C} / \mathrm{min}$, and held at that temperature for $20 \mathrm{~min}$. The temperature was then increased at $5^{\circ} \mathrm{C} / \mathrm{min}$ to $220^{\circ} \mathrm{C}$ and held for $20 \mathrm{~min}$. The injector and detector temperatures were maintained at $240^{\circ} \mathrm{C}$, and the total run time was 94 min. Heptadecadienoic acid was used as a qualitative internal standard. Each peak was identified using known standards of fatty acid and fatty acid methyl esters (Nu-Chek Prep, Elysian, MN; Matreya, Pleasant Gap, PA; and Supelco 37 Component FAME mix, Supelco Inc.). The percentage of each fatty acid was calculated by dividing the area under the fatty acid peak (minus the peak area for heptadecanoic acid) by the sum of the peak areas for all the reported fatty acids. Fatty acids were reported as grams per hundred grams of fatty acid methyl esters.

Data were analyzed using PROC MIXED of SAS (version 9.1; SAS Institute Inc., Cary, NC) as described by Drackley et al. (2007). Briefly, the model contained the random effect of cow and fixed effects of period (i.e., the 5-wk sets of infusion amounts within each treatment; $1 \mathrm{df}$ ), treatment (control or LNA; $1 \mathrm{df}$ ), amount infused (as a subplot; 4 df), and the interaction of treatment and amount ( $4 \mathrm{df}$ ). In this analysis, the statistical parameter of treatment is the interaction of treatment by amount. The effects of amount were tested by using the error term of cow nested within period and treatment. To model the effects of amount and its interaction with treatment, the REPEATED statement within PROC MIXED of SAS was used. Polynomial contrasts were constructed to partition the treatment by amount interaction into single degree of freedom comparisons. The degrees of freedom were determined by using the Kenward-Roger method (Littell et al., 1996). Least squares means were calculated and are presented with their standard errors throughout. Significance was declared at $P<0.05$.

Actual amounts of LCFA infused (Table 3) were slightly less than the target values because of small amounts of the LNA infusate adhering to the sides of the container and variations in pump flow rate. One cow was diagnosed with acute mastitis and medically treated at the end of period 1 . To allow for recovery from mastitis, the infusion was terminated during infusion of $160 \mathrm{~g} / \mathrm{d}$ in period 1 . The cow recovered after $1 \mathrm{wk}$ of treatment during the washout period and returned to infusion in period 2. Therefore, data from this cow were excluded only for $160 \mathrm{~g} / \mathrm{d}$ infusion amount.

Average daily DMI, digestible energy intake (contributed from the diet only), and intakes of LCFA from diet and infusate are presented in Table 3. Total LCFA intake and LNA intake increased linearly as the amount of LNA infusion increased. The daily DMI tended to decrease at the highest LNA infusion amount but differences were not significant. Generally, DMI is affected by postruminal infusion of highly unsaturated fatty acid (Bremmer et al., 1998; Benson et al., 2001) and to a lesser degree by saturated LCFA (Drackley et al., 1992; Bremmer et al., 1998). In the present study, the infusion mixtures contained approximately $82 \%$ LNA, and the maximum amount of LNA-rich fatty acid infused was $160 \mathrm{~g} / \mathrm{d}$ to avoid possible adverse effects on the animals' health. Abomasal infusion of unsaturated LCFA decreased DMI in other studies. However, the degree of decrease of DMI was associated with the amount and saturation of the infused fat (Christensen et al., 1994; Bremmer et al., 1998; Drackley et al., 2007). 
Table 3. Dry matter intake, digestible energy (DE) intake, and intakes of long-chain fatty acids (LCFA) from diet and infusate for the cows infused duodenally with increasing amounts of free $\alpha$-linolenic acid (LNA) ${ }^{1}$

\begin{tabular}{|c|c|c|c|c|c|c|c|c|}
\hline \multirow[b]{2}{*}{ Variable } & \multicolumn{5}{|c|}{ Amount of LNA-rich fatty acid infused, g/d } & \multicolumn{3}{|c|}{ Treatment $\times$ amount,${ }^{2} P$-value } \\
\hline & 0 & 40 & 80 & 120 & 160 & Linear & Quadratic & Cubic \\
\hline DE intake, ${ }^{3} \mathrm{Mcal} / \mathrm{d}$ & $\begin{array}{c}44.5 \pm 2.8 \\
(45.6 \pm 2.7)\end{array}$ & $\begin{array}{c}42.6 \pm 2.8 \\
(44.7 \pm 2.7)\end{array}$ & $\begin{array}{c}43.1 \pm 2.8 \\
(45.0 \pm 2.8)\end{array}$ & $\begin{array}{c}42.1 \pm 2.8 \\
(41.6 \pm 2.8)\end{array}$ & $\begin{array}{c}40.6 \pm 3.0 \\
(41.1 \pm 2.8)\end{array}$ & 0.74 & 0.32 & 0.16 \\
\hline Dietary LCFA intake, $\mathrm{g} / \mathrm{d}$ & $\begin{array}{c}382 \pm 23 \\
(384 \pm 23)\end{array}$ & $\begin{array}{c}362 \pm 23 \\
(374 \pm 23)\end{array}$ & $\begin{array}{c}368 \pm 23 \\
(368 \pm 23)\end{array}$ & $\begin{array}{c}358 \pm 23 \\
(355 \pm 23)\end{array}$ & $\begin{array}{c}349 \pm 25 \\
(352 \pm 23)\end{array}$ & 0.80 & 0.23 & 0.17 \\
\hline Total LCFA intake, ${ }^{4} \mathrm{~g} / \mathrm{d}$ & $\begin{array}{c}382 \pm 21 \\
(384 \pm 23)\end{array}$ & $\begin{array}{c}401 \pm 22 \\
(374 \pm 23)\end{array}$ & $\begin{array}{c}443 \pm 22 \\
(368 \pm 23)\end{array}$ & $\begin{array}{c}475 \pm 22 \\
(355 \pm 23)\end{array}$ & $\begin{array}{c}505 \pm 22 \\
(352 \pm 23)\end{array}$ & 0.0001 & 0.0001 & 0.0046 \\
\hline
\end{tabular}

\footnotetext{
${ }^{1}$ Values in parentheses are LSM for cows infused with control infusate for each corresponding infusion amount.

${ }^{2}$ Treatment $=$ control or LNA; amount = amount of LNA infused $(0,20,40,80$, or $160 \mathrm{~g} / \mathrm{d})$.

${ }^{3}$ Excludes the energy from the LCFA infusion.

${ }^{4}$ Dietary plus infused LCFA.
}

Previous studies have demonstrated that postruminal infusion of $<400 \mathrm{~g} / \mathrm{d}$ of free LCFA had minor effects on DMI (Drackley et al., 2007; Kadegowda et al., 2008). Unsaturated FFA reaching the duodenum were more potent inhibitors of DMI than were unsaturated TG (Litherland et al., 2005). In the present study, DMI was not greatly affected by LNA infusion, likely because of the relatively low amounts of LCFA that were infused duodenally.

Milk production tended to decrease quadratically as LNA infusion increased (Table 4). However, production of $4 \% \mathrm{FCM}$ was not changed by LNA infusion irrespective of the amount LNA infused because milk fat content tended $(P=0.09)$ to increase linearly with the increased amount of LNA infusion. The tendency for milk yield to decrease was likely attributable to reduced nutrient intake. Infusion did not alter diet digestibility (data not presented), and calculated $\mathrm{NE}_{\mathrm{L}}$ intake (including the LCFA infused) was 28.1, 27.1, 27.7, 27.3, and $26.7 \mathrm{Mcal} / \mathrm{d}$ for LNA infusion at $0,40,80,120$, and $160 \mathrm{~g} / \mathrm{d}$, respectively. Infusions of fat, therefore, failed to increase $\mathrm{NE}_{\mathrm{L}}$ because of the subsequent reduction in DMI with LNA infusion. Reductions in milk yield in the current study were less compared with that observed in previous studies when LCFA were infused into the abomasum (Benson et al., 2001; Drackley et al., 2007; Kadegowda et al., 2008) or duodenum (Gagliostro and Chilliard, 1991), but the amount of LCFA infused was also less in the current study. Further studies are needed to explain this discrepancy in milk yield response.

The milk component most sensitive to dietary manipulation is fat content (Jenkins, 1998; Jenkins and McGuire, 2006). In our present experiment, milk fat content tended to increase linearly as LNA infusion amounts increased, whereas milk fat yield was not changed (Table 4). Previous studies indicated that changes in milk fat have been variable when LCFA were infused postruminally. Variability in milk fat may be partially due to stage of lactation or the extent to which DMI was affected by infusion of fat. No changes in milk fat content or yield were observed with LCFA infusion by Drackley et al. (1992) or Christensen et al. (1994). Similar to our present study, milk fat percentages increased with infusions of soy FFA and soy FFA rich in palmitic acid, but this increase was associated with a decrease in milk volume with no change in milk fat secreted (Bremmer et al., 1998). Abomasal infusion of mostly long-chain unsaturated FA increased milk fat percentage and yield in mid-lactation cows (Benson et al., 2001). In our present study, milk fat content tended to increase linearly, likely associated with increased total LCFA intake; however, this tendency failed to increase milk fat yield because milk yield tended to decrease as the amount of LNA infused increased.

Milk protein content and yield were not changed by lipid infusion (Table 4). Milk lactose content and yield were quadratically reduced as the LNA infusion amounts increased. Most theories considered that milk lactose content could not be affected by dietary changes, except under extreme and unusual feeding situations (Jenkins and McGuire, 2006). Milk lactose content was not altered by postruminal infusion of oleic acid (Christensen et al., 1994; Drackley et al., 2007) or linoleic acid (Bremmer et al., 1998). Similar to our present study, milk lactose content and production were reduced linearly when increasing amount of soy FFA $(0,200,400$, and $600 \mathrm{~g} / \mathrm{d})$ infused into abomasums (Litherland et al., 2005), although the reasons remain unclear.

Data from the present study indicated that infusion of LNA significantly altered the fatty acid composition of milk fat (Table 5). Similar changes were observed 
Table 4. Yield and composition of milk from the cows infused duodenally with increasing amounts of free $\alpha$-linolenic acid (LNA) ${ }^{1}$

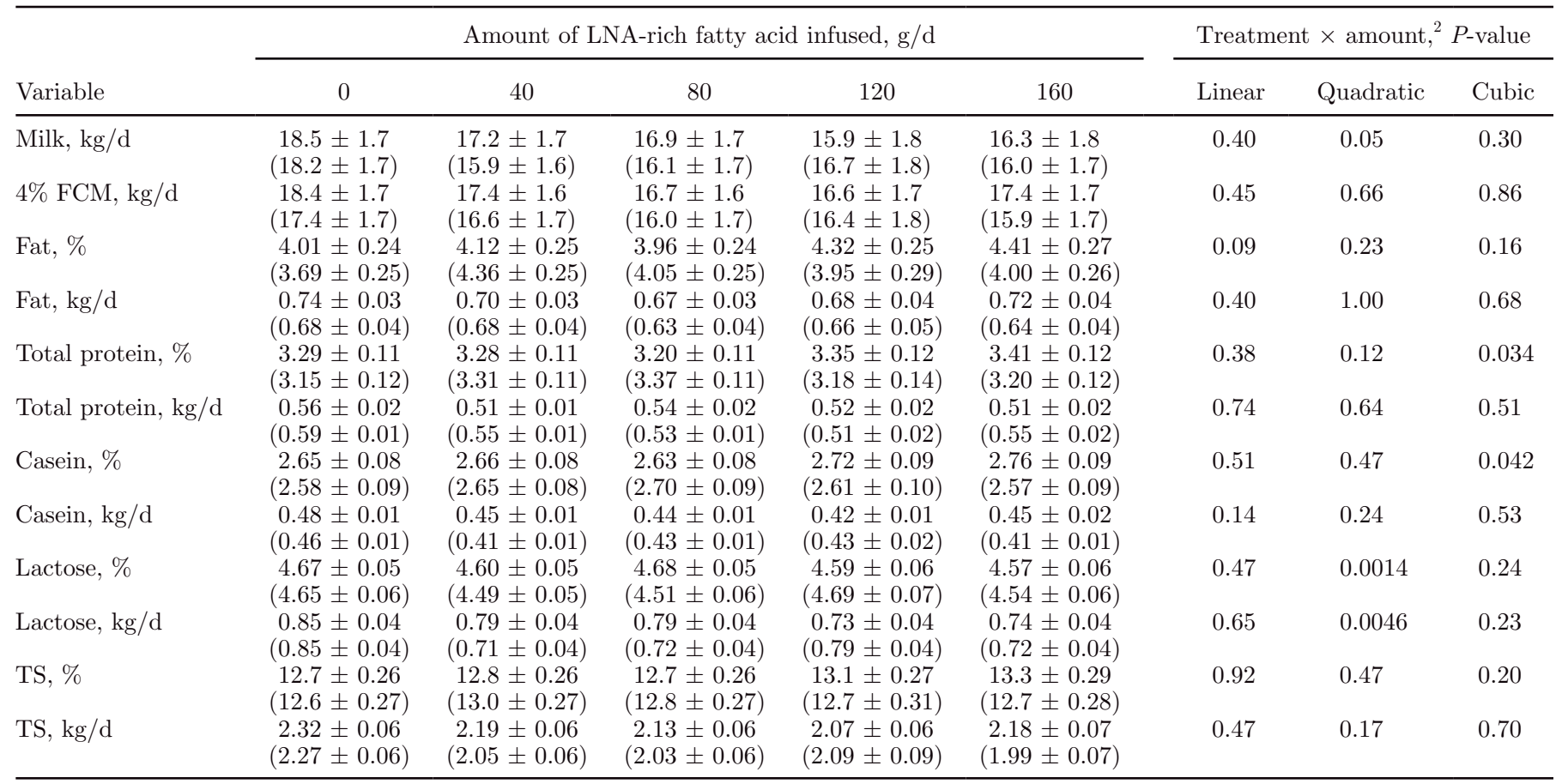

${ }^{1}$ Values in parentheses are LSM for cows infused with control infusate for each corresponding infusion amount.

${ }^{2}$ Treatment $=$ control or LNA; amount $=$ amount of LNA infused $(0,20,40,80$, or $160 \mathrm{~g} / \mathrm{d})$.

when soy FFA (Drackley, et al., 1992; Christensen et al., 1994), high-oleic sunflower FFA (Drackley et al., 2007), or flaxseed oil (Hagemeister et al., 1991) were infused into the abomasum. Increasing the amount of LNA infused into the duodenum linearly decreased the percentages of 4:0, 14:0, and 16:0 fatty acids. Increasing LNA infusion resulted in significant linear decreases in percentages of $18: 1 \mathrm{cis}-9$ and $18: 2$ cis- 9 ,trans- 11 in milk fat. The concentrations of 18:2 cis-9, cis-12, 18:3 cis-9,cis-12,cis-15, 20:3 cis-11,cis-14,cis-19, and $22: 5$ cis-5,cis-7,cis-10,cis-13,cis-16 increased linearly. Milk fat content of 20:5 cis-5,cis-8,cis-11,cis-14,cis-17 was quadratically affected as infusion increased, whereas the concentrations of 18:0, 18:1 trans- $9,18: 1$ trans- 11 , and 18:2 trans-10, cis-12 were not affected.

The percentage of $18: 3$ cis-9, cis-12,cis-15 in the milk fat $(25.4 \%)$ for cows infused with the largest amount of LNA is, to our knowledge, the greatest values reported, by a large margin. The enrichment of LNA in milk fat during infusion of $160 \mathrm{~g} / \mathrm{d}$ of LNA-rich fatty acid (which contained $82.4 \%$ 18:3 cis-9,cis-12,cis-15) was higher than that reported by Hagemeister et al. (1991) who infused cows abomasally with $250 \mathrm{~g} / \mathrm{d}$ linseed oil that contained the same amount of $18: 3$ cis-9, cis12, cis-15 (55.0\%) as our LNA infusion. Possible reasons for this difference may be stage of lactation, milk yield, or the different type of fat infused. In the present study we used free LNA, whereas Hagemeister et al. (1991) infused TG (linseed oil). Similar to the situation for linoleic acid (Litherland et al., 2005), intestinal free LNA may have a greater transfer rate into milk fat than LNA present in TG.

From a quantitative standpoint, the increased incorporation of LNA came primarily at the expense of 14:0, 16:0, and 18:1 cis-9, although other saturated fatty acids and unsaturated fatty acids decreased as well. Decreases in short- and medium-chain fatty acids in milk in response to increased postruminal LCFA supply are consistent with known effects of blood-derived LCFA on de novo fatty acid synthesis in the mammary gland (Palmquist, 1994). The pattern of changes is similar to the effect of mobilization of LCFA from adipose tissue on de novo fatty acid synthesis in the mammary gland during early lactation (Palmquist et al., 1993). In other experiments, postruminal infusion of LCFA to the diet also changed the fatty acid profile of milk in a manner similar to that of this study. Abomasal infusion of increasing amounts of oleic acid (LaCount et al., 1994; Drackley et al., 2007) or linoleic acid (Litherland et al., 2005) decreased the contents of short- and mediumchain fatty acids in milk fat but increased unsaturated C18 fatty acid in milk. Although not determined in our study, the likely mechanism is that postruminal administration of LCFA inhibits activity and expres- 
Table 5. Fatty acids (g/100 g of fatty acid methyl esters) in milk fat from cows infused duodenally with increasing amounts of free $\alpha$-linolenic $\operatorname{acid}(\mathrm{LNA})^{1}$

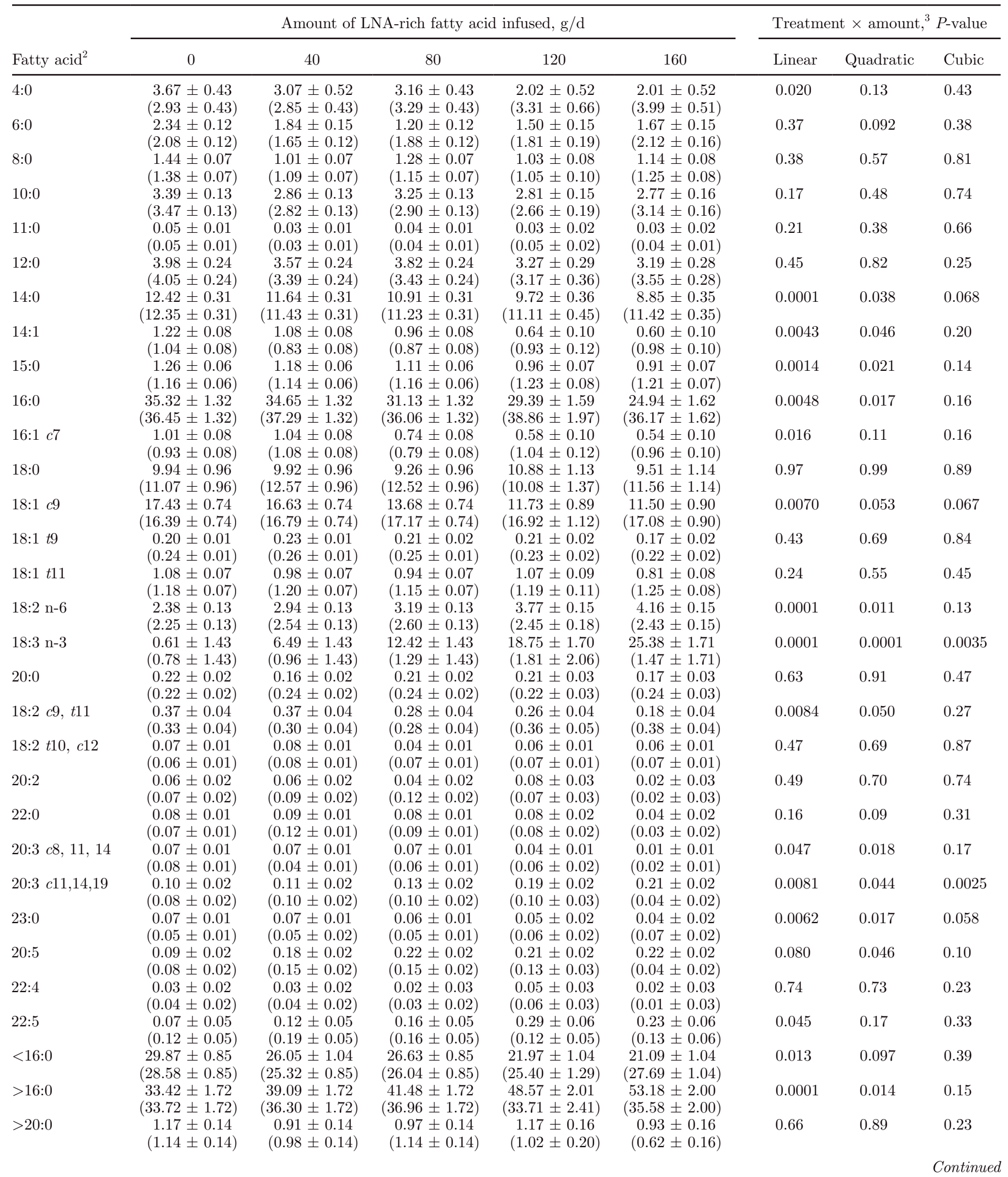


Table 5 (Continued). Fatty acids (g/100 g of fatty acid methyl esters) in milk fat from cows infused duodenally with increasing amounts of free $\alpha$-linolenic acid (LNA) ${ }^{1}$

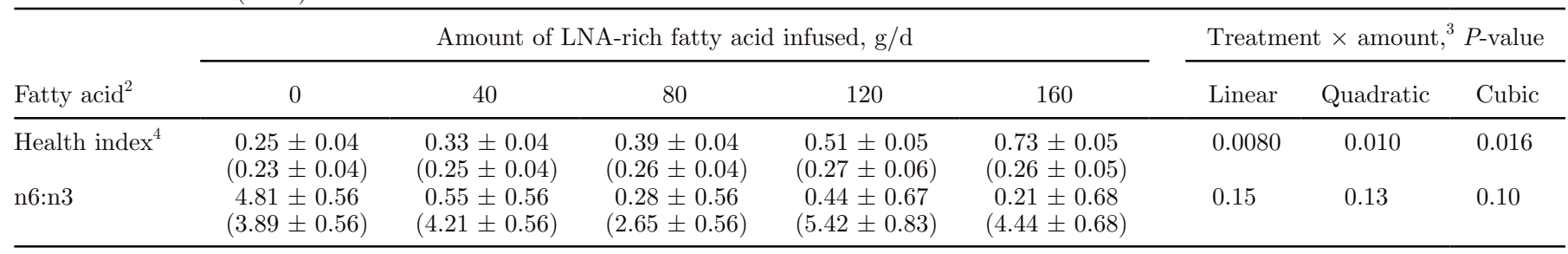

${ }^{1}$ Values in parentheses are LSM for cows infused with control infusate for each corresponding infusion amount.

${ }^{2} c=$ cis; $t=$ trans.

${ }^{3}$ Treatment $=$ control or LNA; amount $=$ amount of LNA infused $(0,20,40,80$, or $160 \mathrm{~g} / \mathrm{d})$.

${ }^{4}$ Calculated as $(16: 1$ cis- $7+18: 1$ cis- $9+18: 2 \mathrm{n}-6+18: 3 \mathrm{n}-3) /[12: 0+(4 \times 14: 0)+16: 0]$, based on Chen et al. (2004).

sion of the enzymes for de novo fatty acid synthesis by mammary gland, as proposed by others (Grummer, 1991; LaCount et al., 1994).

Collectively, increasing the supply of LNA to the intestine up to $120 \mathrm{~g} / \mathrm{d}$ can markedly change the FA composition of milk fat without affecting DMI and nutrient digestibility. The content of LNA in milk fat responds linearly to the amount of intestinally absorbable LNA, primarily at the expense of 14:0 and 16:0 as well as 18:1 cis-9. Thus, these data extend observations demonstrating that the bovine mammary gland has the ability to produce a remarkably different milk fat when presented with a drastically altered profile of milk fat precursors. Such changes in milk fat composition would be expected to have an effect on the nutritional and processing characteristics of milk fat, which would be important to evaluate further.

\section{ACKNOWLEDGMENTS}

This work was funded in part by the Ministry of Agricultural Science and Technology (Nyhyzx07-036-01). The authors thank the staff of the ruminant nutrition lab at the Institute of Animal Science, Chinese Academy of Agricultural Science, for their assistance. We also acknowledge the kind contribution of Zhong-Tang $\mathrm{Yu}$ from Ohio State University for this work.

\section{REFERENCES}

Benson, J. A., C. K. Reynolds, D. J. Humphries, S. M. Rutter, and D. E. Beever. 2001. Effects of abomasal infusion of long-chain fatty acids on intake, feeding behavior and milk production in dairy cows. J. Dairy Sci. 84:1182-1191.

Bremmer, D. R., L. D. Ruppert, J. H. Clark, and J. K. Drackley. 1998. Effects of chain length and unsaturation of fatty acid mixtures infused into the abomasum of lactating dairy cows. J. Dairy Sci. 81:176-188.

Bu, D. P., J. Q. Wang, T. R. Dhiman, and S. J. Liu. 2007. Effectiveness of oils rich in linoleic and linolenic acids to enhance conjugated linoleic acid in milk from dairy cows. J. Dairy Sci. 90:998-1007.
Chen, S., G. Bobe, S. Zimmerman, E. G. Hammond, C. M. Luhman, T. D. Boylston, A. E. Freeman, and D. C. Beitz. 2004. Physical and sensory properties of dairy products from cows with various milk fatty acid compositions. J. Agric. Food Chem. 52:3422-3428.

Chinese Feeding Standard. 2004. China NY/t34: Feeding Standard of Dairy Cattle. China NongYe HangYe Biaozhun/Tuijian-34. China Agricultural Publisher, Beijing, China.

Christensen, R. A., J. K. Drackley, D. W. LaCount, and J. H. Clark. 1994. Infusion of four long-chain fatty acid mixtures into the abomasum of lactating dairy cows. J. Dairy Sci. 77:1052-1069.

Connor, W. E. 1999. Alpha-linolenic acid in health and disease. Am. J. Clin. Nutr. 69:827-828.

Drackley, J. K., T. H. Klusmeyer, A. M. Trusk, and J. H. Clark. 1992. Infusion of long-chain fatty acids varying in saturation and chain length into the abomasum of lactating dairy cows. J. Dairy Sci. $75: 1517-1526$.

Drackley, J. K., T. R. Overton, G. Ortiz-Gonzalez, A. D. Beaulieu, D. M. Barbano, J. M. Lynch, and E. G. Perkins. 2007. Responses to increasing amounts of high-oleic sunflower fatty acids infused into the abomasum of lactating dairy cows. J. Dairy Sci. 90:51655175 .

Flowers, G., S. A. Ibrahim, and A. A. AbuGhazaleh. 2008. Milk fatty acid composition of grazing dairy cows when supplemented with linseed oil. J. Dairy Sci. 91:722-730.

Gagliostro, G., and Y. Chilliard. 1991. Duodenal rapeseed oil infusion in early and midlactation cows. 2. Voluntary intake, milk production, and composition. J. Dairy Sci. 74:499-509.

Grummer, R. R. 1991. Effect of feed on the composition of milk fat. J. Dairy Sci. 74:3244-3257.

Hagemeister, H., D. Precht, M. Franzen, and C. A. Barth. 1991. Alpha-linolenic acid transfer into milk fat and its elongation by cows. Fett Wiss. Technol./Fat Sci. Technol. 93:387-391.

Jenkins, T. C. 1998. Fatty acid composition of milk from Holstein cows fed oleamide or canola oil. J. Dairy Sci. 81:794-800.

Jenkins, T. C., and M. A. McGuire. 2006. Major advances in nutrition: Impact on milk composition. J. Dairy Sci. 89:1302-1310.

Kadegowda, A. K., L. S. Piperova, P. Delmonte, and R. A. Erdman. 2008. Abomasal infusion of butterfat increases milk fat in lactating dairy cows. J. Dairy Sci. 91:2370-2379.

Kramer, J. K., V. Fellner, M. E. Dugan, F. D. Sauer, M. M. Mossoba, and M. P. Yurawecz. 1997. Evaluating acid and base catalysts in the methylation of milk and rumen fatty acids with special emphasis on conjugated dienes and total trans fatty acids. Lipids $32: 1219-1228$

LaCount, D. W., J. K. Drackley, S. O. Laesch, and J. H. Clark. 1994. Secretion of oleic acid in milk fat in response to abomasal infusions of canola or high oleic sunflower fatty acids. J. Dairy Sci. $77: 1372-1385$.

Litherland, N. B., S. Thire, A. D. Beaulieu, C. K. Reynolds, J. A. Benson, and J. K. Drackley. 2005. Dry matter intake is decreased more by abomasal infusion of unsaturated free fatty acids than by unsaturated triglycerides. J. Dairy Sci. 88:632-643. 
Littell, R. C., G. A. Milliken, W. W. Stroup, and R. D. Wolfinger. 1996. SAS System for Mixed Models. SAS Inst. Inc., Cary, NC.

Loor, J. J., A. Ferlay, A. Ollier, M. Doreau, and Y. Chilliard. 2005a. Relationship among trans and conjugated fatty acids and bovine milk fat yield due to dietary concentrate and linseed oil. J. Dairy Sci. 88:726-740.

Loor, J. J., A. Ferlay, A. Ollier, K. Ueda, M. Doreau, and Y. Chilliard. 2005b. High-concentrate diets and polyunsaturated oils alter trans and conjugated isomers in bovine rumen, blood, and milk. J. Dairy Sci. 88:3986-3999.

Palmquist, D. L. 1994. The role of dietary fats in efficiency of ruminants. J. Nutr. 124(Suppl.):1377S-1382S.

Palmquist, D. L., A. D. Beaulieu, and D. M. Barbano. 1993. Feed and animal factors influencing milk fat composition. J. Dairy Sci. $76: 1753-1771$
Petit, H. V. 2003. Digestion, milk production, milk composition, and blood composition of dairy cows fed formaldehyde treated flaxseed or sunflower seed. J. Dairy Sci. 86:2637-2646.

Petit, H. V., N. Gagnon, P. S. Mir, R. Cao, and S. Cui. 2009. Milk concentration of the mammalian lignan enterolactone, milk production, milk fatty acid profile, and digestibility in dairy cows fed diets containing whole flaxseed or flaxseed meal. J. Dairy Res. 76:257-264.

Petit, H. V., C. Germiquet, and D. Lebel. 2004. Effect of feeding whole, unprocessed sunflower seeds and flaxseed on milk production, milk composition, and prostaglandin secretion in dairy cows. J. Dairy Sci. 87:3889-3898. 